\title{
Expansion of the humoral effector cell compartment of both systemic and mucosal immune systems in a weanling murine model which duplicates critical features of human protein-energy malnutrition
}

\author{
BY C.-L. HA, L. E. PAULINO-RACINE AND B. D. WOODWARD* \\ Department of Human Biology and Nutritional Sciences, University of Guelph, Guelph, \\ ON NIG 2W1, Canada
}

(Received 9 January 1995 - Revised 14 June 1995-Accepted 27 June 1995)

\begin{abstract}
A direct comparison of systemic (spleen) and mucosal (intestine) antibody-producing systems was made in weanling male C57BL/6J mice subjected to wasting protein-energy malnutrition (PEM) by means of a low-protein protocol known to duplicate immunological and physiological features of human malnutrition. ELISA revealed low concentrations of biliary and gut lumen immunoglobulin (Ig) $A$ in malnourished mice concomitantly with a high concentration of blood IgA. The low-protein model, therefore, exhibited fidelity to human protein-energy malnutrition in its influence on the concentrations of the mucosal $\mathrm{Ig}, \mathrm{IgA}$, in critical biological fluids. The number of IgA-, IgM- and IgG-containing cells was estimated morphometrically on a per organ basis. The low-protein protocol supported expansion in numbers of mucosal IgA-containing cells (18 $\times$ relative to a zero-time control group) and of splenic IgGcontaining cells $(135 \times)$, albeit an attenuated expansion in comparison with that of well-nourished control animals $(132 \times$ and $571 \times$ respectively relative to zero-time controls). Up to terminal differentiation of Ig-containing cells, systemic and mucosal antibody-producing systems exhibited similarly remarkable resistance to wasting malnutrition. Epithelial transport of IgA may be an aspect of the mucosal antibody response which is particularly sensitive to PEM.
\end{abstract}

Immunoglobulin: IgA: Spleen: Intestine: Protein-energy malnutrition

A substantial body of clinical and experimental information exists documenting the influence of wasting pre-adolescent protein-energy malnutrition (PEM) on acquired humoral immunity, i.e. the antibody response (Chandra, 1991). Pre-adolescent humans suffering from wasting PEM exhibit low concentrations of secretory immunoglobulin (Ig) A antibody in diverse mucosal secretions including those of the gastrointestinal tract, salivary glands, lacrimal glands and nasopharynx (Chandra, 1975; Sirisinha et al. 1975; Reddy et al. 1976; McMurray et al. 1977; Watson et al. 1978). Corroborating results are reported in relation to intestinal and other mucosal secretions of weanling rodents subjected to wasting PEM (Lim et al. 1981; Sullivan et al. 1993). In addition, the antibody response specific to orally administered immunogens appears consistently depressed by PEM in children (Chandra, 1975) and in weanling rodents (Barry \& Pierce, 1979; McGee \& McMurray, $1988 a, b$ ), although the quantity of research on the IgA response to specific antigens in PEM is modest. Inasmuch as the concentration of IgA in mucosal secretions provides an index of the mucosal antibody response following natural exposure to a diverse array of antigens, this acquired immune response appears almost always depressed in wasting PEM. By contrast, blood plasma concentrations of Ig (often considered reflective 
of systemic humoral immunocompetence) usually are unaffected or even elevated by PEM (Keet \& Thom, 1969; Sirisinha et al. 1975; Bell et al. 1976; Reddy et al. 1976; McMurray et al. 1977; Beatty et al. 1983). Moreover, this disease exerts an inconsistent influence, ranging from depression to enhancement, on the humoral response (as discerned by serum titre) to antigens administered systemically (Steihm, 1980; Chandra, 1991).

Taken together, therefore, the thrust of available evidence is that systemic and mucosal antibody responses differ in sensitivity to pre-adolescent PEM (Chandra, 1991), although dissenting evidence must be acknowledged emphasizing resistance to kwashiorkor on the part of gut mucosal IgA production (Bell et al. 1976; Beatty et al. 1983). This concept enjoys general acceptance and prominence in the field of nutritional immunology. At the same time, a direct comparison is lacking of systemic and mucosal immune systems in PEM. The main objective of the present investigation, therefore, was to compare systemic and mucosal antibody-producing systems by means of the same index of outcome in the same experimental model of weanling PEM. Genesis of Ig-containing cells is the last feature common to systemic and mucosal antibody responses. Consequently, the outcome measure selected as a basis for comparison in the present investigation was the number of such cells within selected systemic and mucosal sites, i.e. the size of the respective humoral effector compartments.

With one exception pertaining to the lacrimal gland of the rat (Sullivan et al. 1993), no quantitative information exists as to the influence of PEM on numbers of Ig-containing cells within any organ. Current opinion is based on observational study of histological material (Green \& Heyworth, 1980; Wade et al. 1982; Beatty et al. 1983), a method which provides, at best, only an impression of cellular numbers per unit tissue section area and which is notoriously unreliable for the purpose of comparing relative numbers of structures dispersed throughout sectioned material (Mayhew \& Williams, 1974). Others (Watson, 1984) have previously noted the paucity of reliable information as to the influence of PEM on numbers of Ig-containing cells. This important deficiency in knowledge must not be overlooked on the expectation that numbers of B cells, for which data exist in experimental PEM (Lim et al. 1981; Slobodianik et al. 1984; Woodward \& Miller, 1991), meaningfully reflect numbers of Ig-containing cells (i.e. cells which represent the end-stages of B lineage differentiation) in this disease. Determination of the size of humoral effector compartments on a per organ basis under defined conditions of experimental PEM, therefore, represents a worthwhile objective in its own right.

\section{MATERIALS AND METHODS}

\section{Animals and diets}

Weanling male $\mathrm{C} 57 \mathrm{BL} / 6 \mathrm{~J}$ mice, $18 \mathrm{~d}$ of age, were housed individually in a windowless room maintained at $25-27^{\circ}$ with a photoperiod (fluorescent lighting) of $14 \mathrm{~h}$ light and $10 \mathrm{~h}$ darkness. Mice were acclimated for $1 \mathrm{~d}$ to a complete egg-white-based, purified diet described previously (Filteau \& Woodward, 1984), and were then allocated to experimental groups. A low-protein diet was made by substituting maize starch (St Lawrence Starch Co., Port Credit, Ontario, Canada) for an equal weight of egg white (US Biochemical, Cleveland, OH, USA) in the complete diet. According to the method of the Association of Official Analytical Chemists (Horwitz, 1980), the low-protein and complete diets contained 5 and $190 \mathrm{~g}$ crude protein $/ \mathrm{kg}$ respectively $(\mathrm{N} \times 6.25$; as fed $)$. The diets are isoenergetic, containing approximately $17 \mathrm{~kJ}$ gross energy/g (Filteau \& Woodward, 1984). Animals had free access to diet and tap water throughout the acclimation and experimental periods, and coprophagy was permitted. Animal care and experimental usage were conducted according to the current guidelines of the Canadian Council on Animal Care. 
Expt 1. Concentrations of immunoglobulin $A$ in serum, bile and lumen contents of intestine Following the $1 \mathrm{~d}$ acclimation period, mice were allocated randomly either to the complete diet (group C, $n$ 7) or to the low-protein diet (group LP, $n$ 8) for a $14 \mathrm{~d}$ feeding period. At the end of the experimental period, mice were anaesthetized with Metofane (Pitman-Moore Inc., Washington Crossing, NJ, USA) to permit sampling of blood from the orbital plexus, and (following cervical dislocation) recovery of the lumen contents of the small and large intestines excluding the caecum. Lumen contents were washed out by means of cold phosphate-buffered saline (PBS; $0.01 \mathrm{M}, \mathrm{pH} \mathrm{7.4)}$ in volumes ranging from 4 to $8 \mathrm{ml}$ per sample as required to remove residue from the mucosa. The resulting fluids were centrifuged at $4^{\circ}$ for $10 \mathrm{~min}$ at $12400 \mathrm{~g}$, and the supernatant fraction from each sample was stored at $-80^{\circ}$, as were the samples of serum. A third group of mice was included to serve as zero-time controls. This group (B; $19 \mathrm{~d}$ of age, $n 4$ ) was subjected only to the acclimation procedure. Carcasses were stored at $-20^{\circ}$ while awaiting compositional analysis.

A subsequent study was conducted for measurement of biliary IgA concentration. Sample sizes were eight, nine and ten mice for groups B, C and LP respectively. Bile was obtained by means of a 27.5 gauge needle inserted into the gall bladder of animals killed by cervical dislocation under Metofane anaesthesia. Samples of bile were stored at $-80^{\circ}$ until analysed. Carcasses were stored at $-20^{\circ}$ and were pooled, within groups, for compositional analysis.

\section{Expt 2. Splenic and intestinal immunoglobulin-containing cells of animals not subjected to systemic immunization}

Following the $1 \mathrm{~d}$ acclimation period, mice were allotted randomly either to the complete diet (group C, $n 7$ ) or to the low-protein diet (group LP, $n 7$ ) for a $14 \mathrm{~d}$ feeding period. Animals were killed by cervical dislocation under light anaesthesia with Metofane (PitmanMoore Inc.) and both spleen and intestine, excluding caecum, were excised for microscopy. A zero-time control group (B; $19 \mathrm{~d}$ of age, $n$ 6) was also included, having been subjected only to the acclimation procedure. All carcasses were stored at $-20^{\circ}$ while awaiting compositional analysis.

\section{Expt 3. Splenic immunoglobulin-containing cells of animals subjected to systemic immunization}

Mice were given intraperitoneal injections either of saline (sterile pyrogen-free physiological saline $(9 \mathrm{~g} \mathrm{NaCl} / 1)$; MTC Pharmaceuticals, Cambridge, Ontario, Canada) or of $4 \times 10^{8}$ sheep erythrocytes (SRBC; Woodlyn Laboratories, Guelph, Ontario, Canada) washed and suspended in saline. Injections were given aseptically at 12, 18,24 and $30 \mathrm{~d}$ of age, and each comprised a volume of $0.1 \mathrm{ml}$. All animals were weaned at $18 \mathrm{~d}$ of age and were acclimated for $1 \mathrm{~d}$ to the complete purified diet used in the preceding two experiments. Following the acclimation period, mice within both the saline- and SRBC-injected groups were fed for $14 \mathrm{~d}$ on either the complete diet (C: saline, $n 4$ and $\mathrm{C}: \mathrm{SRBC}, n 8$ respectively) or the LP formulation used in the other studies of the present investigation (LP:saline, $n 4$ and LP:SRBC, $n 8$ respectively). In addition, a fifth group of mice was killed immediately following the acclimation period (i.e. B; $19 \mathrm{~d}$ of age, $n 7$ ), having received injections of $\mathrm{SRBC}$ at 12 and $18 \mathrm{~d}$ of age. All carcasses were stored at $-20^{\circ}$ while awaiting compositional analysis.

Animals subjected to oral challenge with a defined antigen were not included in the present investigation. In the first place, mice immunized orally, e.g. with SRBC (McGee \& McMurray $1988 a, b$ ), generate mucosal IgA antibody (specific to the challenge) according to kinetics which differ from those of a systemic antibody response. Direct comparison was 
precluded, therefore, of the response to a defined antigen on the part of mucosal and systemic antibody-producing systems. Second, the main antigenic stimulus eliciting the intestinal IgA-containing cell population derives from the gut microflora (Crabbe et al. 1968). Consequently, the results of Expt 2 illustrate, without need of further experimentation, the influence of the LP protocol on the ability to generate intestinal IgAcontaining cells in response to mucosal challenge.

\section{Measurement of immunoglobulin $A$ concentration}

A standard sandwich ELISA technique (Harlow \& Lane, 1988) was used with some modifications. Briefly, ninety-six-well U-bottom plates (Falcon 3910; Becton Dickinson, Oxnard, CA, USA) were coated by incubation overnight at $4^{\circ}$ with affinity purified goat antimouse IgA (Sigma Chemical Co., St Louis, MO, USA; $\alpha$-chain-specific, $1 \mu \mathrm{g} /$ well in $100 \mu \mathrm{l}$ PBS). Plates were washed at this stage, and at subsequent stages of the procedure, with $0.5 \mathrm{~g}$ Tween 20/1 PBS. The blocking solution consisted of PBS containing $30 \mathrm{~g}$ bovine serum albumin (BSA; fraction V; Sigma Chemical Co.)/1. Samples diluted appropriately in PBS were incubated in $100 \mu \mathrm{l}$ quantities at $37^{\circ}$ for $1 \mathrm{~h}$. The second antibody was peroxidase (EC 1.11.1.7)-conjugated goat anti-mouse IgA ( $\alpha$-chain-specific; Nordic Immunological Laboratories, Maidenhead, Berks.), and $100 \mu \mathrm{l}$ was added to each well for $1 \mathrm{~h}$ at $37^{\circ}$ at a dilution of $1: 1500$ in PBS containing $10 \mathrm{~g} \mathrm{BSA} / 1$. The developing solution (100 $\mu \mathrm{l}$ per well) contained $400 \mathrm{mg} o$-phenylenediamine dihydrochloride (Sigma Chemical Co.) $/ 1$ and 3.5 mmol $\mathrm{H}_{2} \mathrm{O}_{2}$ (certified ACS; Fisher Scientific, Don Mills, Ontario, Canada) $/ 1$ in $50 \mathrm{mmol}$ phosphate-citrate/l buffer adjusted to $\mathrm{pH} 5 \cdot 0$. The reaction was stopped with $50 \mu \mathrm{l} 3 \mathrm{M}-$ $\mathrm{HCl}$ and the optical density of the fluid in each well was determined by means of a $V_{\max }$ Kinetic Microplate Reader (Molecular Devices Corp., Menlo Park, CA, USA) fitted with a $490 \mathrm{~nm}$ filter. A standard curve was constructed for each assay using purified mouse myeloma IgA (clone: TEPC 15; Sigma Chemical Co.) and, in each case, $r^{2}>0.98$. In addition, the efficiency with which IgA could be detected in each sample was quantified by means of an internal standard of $10 \mathrm{ng}$ mouse myeloma IgA. Detection efficiency was $100 \%$ for serum, and averaged $60 \%$ both for the samples of intestinal contents and for the bile samples.

\section{Preparation of tissues for microscopy}

The small intestine was divided into five equal lengths from which the contents were washed by means of cold PBS. The washed segments of small intestine as well as the colon, similarly washed, were blotted and weighed. A $5 \mathrm{~mm}$ length of tissue was removed from the midpoint of each segment for fixation in ethanol-glacial acetic acid at $4^{\circ}$ as described elsewhere (Ojeda et al. 1989). The spleen, trimmed of adherent fat, was prepared in a similar manner, and was fixed either as an intact organ (Expt 3) or in blocks approximately $2 \mathrm{~mm}$ in thickness (Expt 2). Tissue was embedded in Paraplast Plus (Fisher Scientific).

\section{Immunohistochemical identification of immunoglobulin-containing cells}

Non-consecutive $5 \mu \mathrm{m}$ sections were used, having been cut at least $15 \mu \mathrm{m}$ distant from one another. Immunohistochemical staining was conducted according to a standard method (van Noorden, 1986) with modifications. Briefly, sections were incubated for $30 \mathrm{~min}$ at room temperature in peroxidase-conjugated goat anti-mouse IgA, anti-mouse IgM, or antimouse IgG (Nordic Immunological Laboratories) at dilutions of 1:500, 1:500, and 1:400 respectively in PBS containing $10 \mathrm{~g}$ BSA/1. Slides were then incubated for $4 \mathrm{~min}$ at room temperature in PBS containing 0.25 g 3,3'-diaminobenzidine tetrahydrochloride (Aldrich Chemical Co., Milwaukee, WI, USA) $/ 1$ and $0.225 \mathrm{~g} \mathrm{H}_{2} \mathrm{O}_{2}$ (certified ACS; Fisher Scientific)/1. Endogenous peroxidase activity was blocked with $100 \mathrm{~g} \mathrm{H}_{2} \mathrm{O}_{2} / 1$ in distilled water. Sections were counter-stained lightly with haematoxylin. 
Murine kidney sections served as negative control tissue and failed to exhibit a positive reaction with any of the three peroxidase conjugates. The specificity of the anti-Ig reagents was verified using preparations of purified mouse myeloma IgA and IgM (clones: TEPC 15 and TEPC 183 respectively; Sigma Chemical Co.) and of purified mouse IgG (reagent grade, catalogue no. I5381; Sigma Chemical Co.), each of which could eliminate positive reaction with the corresponding peroxidase conjugate only.

\section{Estimation of numbers of immunoglobulin-containing cells in spleen and intestinal lamina propria}

Ig-containing cells were identified at $400 \times$ magnification, and their numbers per unit tissue volume were quantified according to the morphometric procedure described by Weibel \& Bolender (1973). The following formula was used:

$$
\mathrm{N}_{\mathrm{v}}=\mathrm{N}_{\mathrm{A}} / \mathrm{D} \text {, }
$$

where $N_{V}$ is the number of cells per unit tissue volume, $N_{A}$ is the number of cells per unit section area examined and $D$ is average cellular diameter. Section area was estimated at $100 \times$ magnification using an ocular reticle with a regular quadratic lattice of $1 \mathrm{~mm}$ spacing such that, by the principle of areal analysis discussed elsewhere (Weibel \& Bolender, 1973), each point represented $0.01 \mathrm{~mm}^{2}$ of sectioned tissue. D, estimated to be $8.68 \mu \mathrm{m}$, was determined as the average of the minimum and maximum diameters of $250 \mathrm{Ig}$-containing cells, and did not differ between well-nourished and malnourished groups. Measurements used to estimate $\mathrm{D}$ were made at $1000 \times$ magnification using an ocular micrometer which was calibrated by means of a stage micrometer accurate to $0.01 \mu \mathrm{m}$ (Bausch \& Lomb Optical Co., Rochester, NY, USA). In order to convert $\mathrm{N}_{\mathrm{v}}$ to cellular numbers per unit organ weight, tissue density was assumed to be $1 \mathrm{mg} / \mathrm{mm}^{3}$. At least $3 \mathrm{~mm}^{2}$ of splenic section area and $17 \mathrm{~mm}^{2}$ of intestinal section area (range up to $40 \mathrm{~mm}^{2}$ and $55 \mathrm{~mm}^{2}$ respectively) was sampled from each mouse. The size necessary for each sample was determined on the basis of the numbers of Ig-containing cells encountered.

\section{Carcass analyses}

Analysis of dry matter, crude protein and lipid content of mouse carcasses is described elsewhere (Woods \& Woodward, 1991).

\section{Statistical analyses}

Statistical analysis was performed according to the SAS Guide (Statistical Analysis Systems, 1985). Results were subjected to two-tailed Student's $t$-test or to ANOVA followed, if justified, by Duncan's new multiple-range test. Data that were not normally distributed, and that could not be normalized by either logarithmic or square-root transformation, were analysed by the Wilcoxon two-sample test or (for comparison of more than two groups) by the Kruskal-Wallis test (chi-square approximation) applied to Wilcoxon rank sums. Where warranted by the resulting statistical probability value (i.e. $P<0.05$ ), the latter procedure was followed by chi-square comparisons of Wilcoxon twosample rank sums. The pre-determined upper limit of probability for statistical significance throughout this investigation was $P<0.05$.

\section{RESULTS}

Growth indices are shown in Table 1. Weight loss of the malnourished groups was comparable among the several experiments, and averaged between 23 and $29 \%$ of initial body weight. Loss of weight occurred in an approximately linear manner throughout the $14 \mathrm{~d}$ experimental period (results not shown). Decrements were induced in both lean and 
Table 1. Expts 1-3. Growth indices for 33-d-old weanling mice fed ad lib. on complete (C) or low-protein (LP) diets for $14 d$ and for 19-d-old zero-time controls $(B)^{*}$

\begin{tabular}{|c|c|c|c|c|c|c|c|}
\hline \multirow{3}{*}{$\begin{array}{l}\text { Treatment } \\
\text { group }\end{array}$} & \multirow[b]{3}{*}{$n$} & \multirow{2}{*}{\multicolumn{2}{|c|}{ Weight (g/mouse) }} & \multirow{3}{*}{$\begin{array}{c}\text { Feed intake } \\
\text { (g/mouse for } \\
14 \mathrm{~d} \text { ) }\end{array}$} & \multicolumn{3}{|c|}{ Carcass compositions (g/ $\mathrm{kg}$ wet wt) } \\
\hline & & & & & & Crude protein & \\
\hline & & Initial & Final & & Dry matter & $(\mathrm{N} \times 6.25)$ & Lipid \\
\hline \multicolumn{8}{|c|}{ Expt $1 . \operatorname{Ig} A$ in serum and intestinal lumen } \\
\hline B & 4 & $8 \cdot 7$ & - & - & $300^{\mathrm{a}}$ & $155^{\mathrm{b}}$ & $91^{a}$ \\
\hline $\mathrm{C}$ & 7 & $8 \cdot 9$ & $20 \cdot 8^{\mathrm{a}}$ & $40 \cdot 7^{\mathrm{a}}$ & $296^{\mathrm{a}}$ & $169^{a}$ & $81^{a}$ \\
\hline LP & 8 & $8 \cdot 8$ & 6.4 & $17 \cdot 5$ & $276^{\mathrm{b}}$ & $164^{\mathrm{ab}}$ & $35^{b}$ \\
\hline SEM & & $-\dagger$ & - & $-\S$ & $4 \cdot 6$ & 3.5 & $5 \cdot 0$ \\
\hline \multicolumn{8}{|c|}{ Expt 1. IgA in bile } \\
\hline B & 8 & 8.9 & - & - & 270 & 136 & 70 \\
\hline $\mathbf{C}$ & 9 & $8 \cdot 6$ & $20 \cdot 4^{a}$ & $44 \cdot 3^{\mathrm{a}}$ & 270 & 158 & 57 \\
\hline LP & 10 & $8 \cdot 6$ & 6.5 & $18 \cdot 0$ & 270 & 156 & 41 \\
\hline SEM & & $-\|$ & $2 \cdot 01$ & 0.23 & -9 & - & -9 \\
\hline \multicolumn{8}{|c|}{ Expt 2. Ig-containing cells of unimmunized mice } \\
\hline B & 6 & $8 \cdot 6$ & - & - & - & - & - \\
\hline $\mathrm{C}$ & 7 & $8 \cdot 7$ & $20 \cdot 8^{a}$ & $47 \cdot 1^{a}$ & $280^{a}$ & 157 & $67^{\mathrm{a}}$ \\
\hline LP & 7 & $8 \cdot 6$ & 6.6 & 20.9 & 263 & 154 & 36 \\
\hline SEM & & 0.14 & 0.21 & 1.82 & $3 \cdot 8$ & $2 \cdot 1$ & $4 \cdot 6$ \\
\hline \multicolumn{8}{|c|}{ Expt 3 . Ig-containing cells of systemically immunized mice } \\
\hline B & 7 & $9 \cdot 7$ & - & - & - & - & - \\
\hline C:saline & 4 & $9 \cdot 0$ & $20 \cdot 8^{\mathrm{a}}$ & $46 \cdot 2^{a}$ & $287^{a}$ & 164 & $64^{\mathrm{a}}$ \\
\hline C:SRBC & 8 & $9 \cdot 5$ & $21 \cdot 8^{\mathrm{a}}$ & $50 \cdot 2^{a}$ & $292^{\mathrm{a}}$ & 168 & $68^{\mathrm{a}}$ \\
\hline LP: saline & 4 & $8 \cdot 8$ & $6 \cdot 2^{\mathrm{C}}$ & $20 \cdot 6^{\mathrm{b}}$ & $274^{\mathrm{b}}$ & 162 & $29^{\mathrm{b}}$ \\
\hline LP:SRBC & 7 & $9 \cdot 6$ & $7 \cdot 0^{b}$ & $20 \cdot 9^{b}$ & $274^{b}$ & 163 & $33^{b}$ \\
\hline SEM & & 0.37 & 0.04 & 0.06 & $2 \cdot 9$ & $3 \cdot 7$ & $3 \cdot 5$ \\
\hline
\end{tabular}

a. b.e Within an experiment and column, values not sharing a common superscript letter were significantly different $(P<0.05)$ according to two-tailed Student's $t$ test or to Duncan's new multiple-range test (comparison of two means or of three or more means respectively), or according to the Wilcoxon two-sample test or the Kruskal-Wallis test (comparison of two groups or of three groups respectively) if data could not be normalized by transformation procedures.

C:saline, C: SRBC, LP: saline, LP:SRBC, in Expt 3, animals were given injections either of saline $(9 \mathrm{~g} \mathrm{NaCl} / \mathrm{l})$ or of sheep erythrocytes (SRBC), as indicated, at 12,18,24 and $30 \mathrm{~d}$ of age, except group B which received SRBC at 12 and $18 \mathrm{~d}$ of age only.

* For details of experimental procedures, see pp. 446-449.

† Kruskal-Wallis rank sums: B 29, C 78, LP 83.

Wilcoxon two-sample rank sums: C 84, LP 36.

$\S$ Wilcoxon two-sample rank sums: C 84, LP 36.

|| Kruskal-Wallis test of Wilcoxon rank sums which were as follows: B 128, C 116.5, LP 133.5.

II Each value is from a triplicate assay of a single pooled sample.

fat tissue of LP mice, particularly in fat tissue which was found in reduced proportions in the malnourished animals. Although feed intake was lower in the malnourished mice than in the well-nourished animals, the wasting induced by the LP diet is attributable to the dietary imbalance and not to an insufficient intake of energy or micronutrients. LP mice consumed between 41 and $44 \%$ of group $\mathrm{C}$ intakes and, in relation to metabolic body weight (body weight ${ }^{0.75}$ ), this represents excessive intake relative to control animals. Wasting PEM, therefore, was produced in the present investigation and in each experiment was closely similar to the condition shown in previous studies of the same experimental system (Woodward \& Miller, 1991; Woods \& Woodward, 1991) to be associated with depression in cell-mediated and systemic humoral acquired immunity. 
Table 2. Expt 1. Immunoglobulin (Ig) $A$ in serum, bile and lumen contents of the intestines of 33-d-old weanling mice fed ad lib. on complete $(C)$ or low-protein $(L P)$ diets for $14 d$ and for 19-d-old zero-time controls $(B)^{*}$

\begin{tabular}{lccc}
\hline \hline $\begin{array}{l}\text { Treatment } \\
\text { group }\end{array}$ & Serum $(\mu \mathrm{g} / \mathrm{ml}) \dagger$ & Bile $(\mu \mathrm{g} / \mathrm{ml}) \dagger$ & $\begin{array}{c}\text { Intestinal content } \\
(\mu \mathrm{g} / \text { mouse }) \dagger\end{array}$ \\
\hline B & $40^{\mathrm{e}}$ & $17^{\mathrm{b}}$ & $14^{\mathrm{b}}$ \\
C & $193^{\mathrm{b}}$ & $360^{\mathrm{a}}$ & $180^{\mathrm{a}}$ \\
LP & $532^{\mathrm{a}}$ & $22^{\mathrm{b}}$ & $8^{\mathrm{b}}$ \\
SEM & $0 \cdot 10$ & $0 \cdot 46$ & $0 \cdot 17$ \\
\hline \hline
\end{tabular}

a.b.c Within each column, values not sharing a common superscript letter were significantly different $(P<0.05)$ according to Duncan's new multiple-range test; $n$ 4, 7 and 8 for groups $B, C$ and LP respectively except for bile in which the corresponding values for $n$ were 8,9 and 10 .

* For details of experimental procedures, see pp. 446-449.

$\dagger$ Means are anti-logs of natural log-transformed means.

IgA concentrations of serum and bile and the quantity of $\operatorname{IgA}$ in the lumen contents of the intestine are presented in Table 2 . The results pertaining to group $\mathrm{C}$ mice are comparable with findings reported by other laboratories for this species (McGee \& McMurray, 1988a; Delacroix et al. 1985). Serum IgA concentration rose between 19 and $33 \mathrm{~d}$ of age in animals of both groups $\mathrm{C}$ and LP, but was higher in the malnourished mice at the end of the experiment. By contrast, only group $\mathrm{C}$ exhibited a biliary $\operatorname{IgA}$ concentration and an intestinal content of $\operatorname{IgA}$ which were above the levels exhibited by the zero-time control group. It is noteworthy that wasting PEM in humans is characterized by a low IgA concentration in intestinal contents (Reddy et al. 1976) coupled frequently with a normal or even elevated level of IgA in the blood plasma (Keet \& Thom, 1969; Sirisinha et al. 1975; Reddy et al. 1976; Beatty et al. 1983). The LP system used herein, therefore, mimics these important and basic features of human PEM in relation to IgA-class Ig. At the same time, the LP protocol exerted no effect on serum IgM concentration which rose to the same extent, relative to the level determined in zero-time controls, in groups $\mathrm{C}$ and LP (anti-logs of natural log-transformed means 37,102 and $121 \mu \mathrm{g} / \mathrm{ml}$ in groups B, C and LP respectively; pooled SEM $0 \cdot 085$, error df 16 ). IgM was quantified by sandwich ELISA as described for serum IgA except for use of peroxidase-conjugated goat anti-mouse IgM (Nordic Immunological Laboratories). This finding, also, is consistent with previous results pertaining to wasting PEM in humans (Reddy et al. 1976; McMurray et al. 1977).

It was possible that a substantial proportion of the gut lumen IgA of group B animals was carried over from recent milk ingestion. Such carry-over could confound the conclusion that the gut lumen IgA content of LP mice was reduced below the level exhibited by zero-time controls (group B). To detect a potential carry-over effect, two groups of male C57BL/6J mice ( $n 4$, each) were given a $2 \mathrm{~d}$ post-weaning acclimation period rather than the $1 \mathrm{~d}$ period afforded group B animals. The acclimation periods extended from days 17 to 19 of age, or from days 18 to 20 of age, after which gut lumen IgA contents were (mean; $\mu \mathrm{g}$ per animal) 26 (SD 18) and 19 (SD 18) respectively. On the basis of inspection, these values do not differ from the lumen IgA content of group B animals (Table 2) so that substantial carry-over of milk IgA through the acclimation period appears unlikely.

Fig. 1 contains photographs of sections of small intestine from mice of Expt 2, i.e. animals which were not subjected to systemic immunization. The sections are stained to reveal IgA-containing cells. Results of similar quality (not shown) permitted identification 


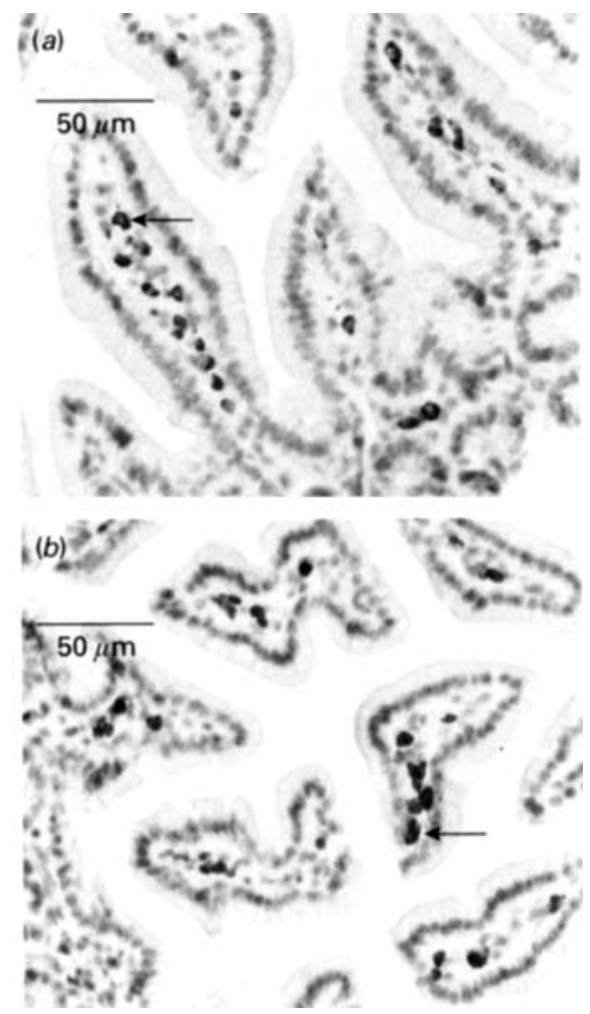

Fig. 1. Expt 2. Sections of duodenum stained to reveal immunoglobulin A-containing cells $(\leftarrow)$ in lamina propria from $(a)$ mouse fed on complete diet, $(b)$ mouse fed on low-protein diet. Haematoxylin counterstain. For details of experimental procedures, see pp. $446-449$.

of intestinal IgM- and IgG-containing cells as well as of IgA-, IgM- and IgG-containing cells of the spleen. When expressed per $\mathrm{mm}^{2}$ section area, the number of intestinal IgA- and IgM-containing cells was higher in group $C$ mice than in LP animals, but both groups exhibited a large increase relative to zero-time controls (Table 3). In the case of the LP group this finding is attributable, in small measure, to the modest degree of intestinal atrophy which was induced by the imbalanced diet (Table 3). By contrast, splenic involution was profound in LP mice (Table 3), as is to be expected in wasting PEM both in humans (Gross \& Newberne, 1980) and in experimental animals (Woods \& Woodward, 1991). Consequently, the numbers of Ig-containing cells per $\mathrm{mm}^{2}$ splenic section area were not low in LP mice relative to group C (Table 3). Numbers of intestinal IgG-containing cells were low in all groups of animals (virtually undetectable in groups B and LP) and, hence, were not quantified.

Numbers of IgA- and IgM-containing cells within the intestinal lamina propria are shown on a per organ basis in Fig. 2 for those mice not subjected to systemic immunization (Expt 2). Both groups $\mathrm{C}$ and LP exhibited a large increase in IgA-containing cellular numbers relative to the zero-time control group, i.e. 132- and 18-fold respectively. In the same study, group $\mathrm{C}$ mice exhibited an increase, relative to zero-time controls, in numbers of splenic IgA-, IgM-and IgG-containing cells, and LP mice supported growth in numbers of IgA- and IgG-containing spleen cells (Fig. 3). By contrast, no change was found in the numbers of splenic IgM-containing cells in LP mice relative to zero-time controls (Fig. 3).

The intestinal mucosa is under constant challenge from microfloral and food-derived 
Table 3. Expt 2. Intestine and spleen: organ size and numbers of immunoglobulin (Ig)containing cells per unit of tissue section area for 33-d-old mice fed ad lib. on complete $(C)$ or low-protein $(L P)$ diets for $14 d$ and for 19-d-old zero-time controls $(B)^{*}$

\begin{tabular}{|c|c|c|c|c|}
\hline Treatment group... & B & $\mathrm{C}$ & $\mathbf{L P}$ & SEM \\
\hline \multicolumn{5}{|l|}{ Intestine $\dagger$} \\
\hline $\mathrm{Wt}(\mathrm{g} /$ mouse $) \ddagger$ & $0.4^{\mathrm{b}}$ & $1 \cdot 0^{\mathrm{a}}$ & $0 \cdot 3^{c}$ & 0.03 \\
\hline Length ( $\mathrm{mm} /$ mouse) & $263^{\mathrm{b}}$ & $383^{a}$ & $248^{\mathrm{b}}$ & 4.2 \\
\hline $\mathbf{N}_{\mathbf{A}}:$ & $\mathrm{c}$ & a & b & \\
\hline $\operatorname{IgA}\left(/ \mathrm{mm}^{2}\right) \ddagger$ & 4 & 230 & 94 & 0.13 \\
\hline $\operatorname{IgM}\left(/ \mathrm{mm}^{2}\right) \ddagger$ & $1^{\mathrm{e}}$ & $23^{a}$ & $6^{b}$ & 0.24 \\
\hline \multicolumn{5}{|l|}{ Spleen } \\
\hline Wt (mg/mouse) & $43^{b}$ & $93^{\mathrm{a}}$ & $9^{\mathrm{c}}$ & 0.07 \\
\hline $\mathrm{N}_{\mathrm{A}}$ : & c & b & a & \\
\hline $\operatorname{IgM}\left(/ \mathrm{mm}^{2}\right) \ddagger$ & 17 & 34 & 101 & 0.21 \\
\hline $\operatorname{IgG}\left(/ \mathrm{mm}^{2}\right)$ & $0 \cdot 1^{b}$ & $9^{b}$ & $22^{\mathrm{a}}$ & 3.63 \\
\hline $\operatorname{IgA}\left(/ \mathrm{mm}^{2}\right)$ & $1^{\mathrm{b}}$ & $14^{\mathrm{a}}$ & $12^{\mathrm{a}}$ & $2 \cdot 48$ \\
\hline
\end{tabular}

$\mathrm{a}, \mathrm{b}, \mathrm{c}$ Within a row, values not sharing a common superscript letter were significantly different $(P<0.05)$ according to Duncan's new multiple-range test.

$\mathrm{N}_{\mathrm{A}}$, no. of cells per unit tissue section area containing antibody of classes designated IgA, IgM or IgG.

* For details of experimental procedures, see pp. 446-449.

$\dagger$ Small and large intestine excluding caecum.

$\ddagger$ Means are anti-logs of natural log-transformed means.

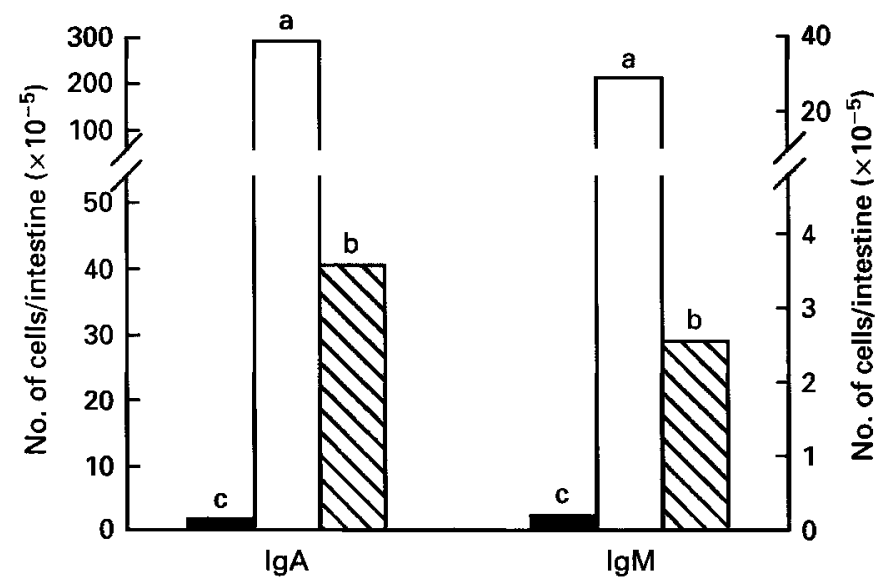

Fig. 2. Expt 2. Numbers of cells containing immunoglobulin (Ig) of either IgA or IgM class within intestinal lamina propria. Values represent anti-logs of natural log-transformed mean values. Within each Ig class, values not sharing a common superscript letter were significantly different $(P<0.05)$ according to Duncan's new multiple-range test. Pooled SEM 0.1241 and 0.2463 for nos. (natural log-transformed data) of IgA- and IgMcontaining cells respectively. ( $\square$ ), Group B, $n 6,19$-d-old zero-time control; ( $\square$ ), group C, $n$ 7, 33-d-old, complete diet ad lib. for $14 \mathrm{~d}$; $(\mathbb{S})$, group LP, $n$ 7, 33-d-old, low-protein diet ad lib. for $14 \mathrm{~d}$. For details of experimental procedures, see pp. 446-449.

antigens. It was important, therefore, to include study of the antigen-challenged spleen in the present investigation. In the study of immunized mice (Expt 3 ) the numbers of IgM- and IgG-containing spleen cells found in the saline-injected groups (Fig. 4) were comparable to the estimates obtained for the corresponding groups, $\mathrm{C}$ and LP, in the preceding experiment (Fig. 3). The large number of immunoglobulin-containing spleen cells found in 


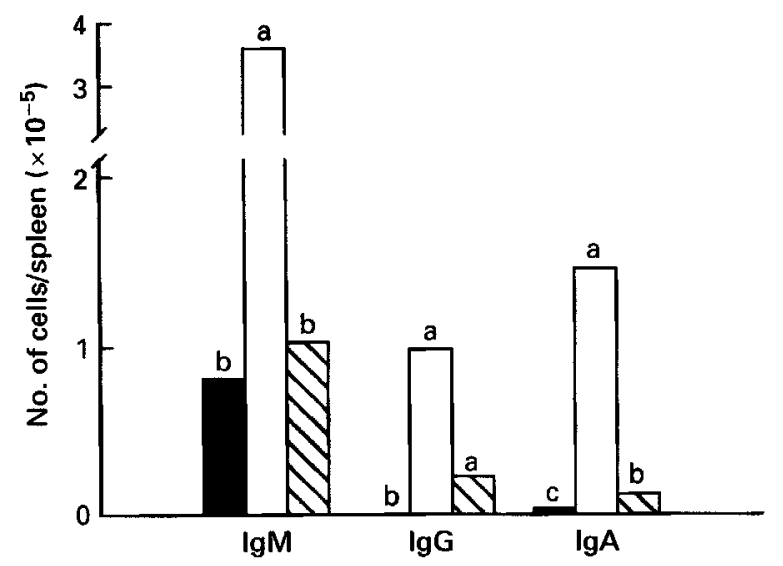

Fig. 3. Expt 2. Numbers of spleen cells containing immunoglobulin (Ig) of IgM, IgG or IgA class. Values are means and, in the case of IgM, anti-logs of natural log-transformed means. Within each Ig class, values not sharing a common superscript letter were significantly different $(P<0.05)$ according to either Duncan's new multiple-range test (IgM) or Wilcoxon two-sample tests which were conducted following Kruskal-Wallis comparison of Wilcoxon rank sums (IgG, IgA). Pooled SEM (IgM, natural log-transformed data) $0 \cdot 2155$, whereas Wilcoxon rank sums were (IgG) 24.5, 82.5 and 83, and (IgA) 27, 98 and 65 (groups B, C and LP respectively for each Ig class). ( $\square$ ), Group B, $n$ 6, 19-d-old zero-time control; ( $\square$ ), group C, $\boldsymbol{n}$ 6, 33-d-old, complete diet ad lib. for $14 \mathrm{~d}$; $(\mathbb{\Xi})$, group LP, $n$ 7, 33-d-old, low-protein diet ad lib. for $14 \mathrm{~d}$. Mean value for number of IgG-containing cells of group B is 172 per spleen. For details of experimental procedures, see pp. 446-449.

group B of Expt 3 (Fig. 4) reflects the impact of systemic SRBC challenge on these animals. Systemic exposure to SRBC produced a large increase in the number of IgM- and IgGcontaining cells in the spleen of group $\mathrm{C}$ animals as well as of IgG-containing cells in the spleen of LP mice when compared either to the corresponding saline-injected group or to the zero-time controls (Fig. 4). Injections of SRBC, however, produced no effect on the number of IgM-containing spleen cells in LP animals (Fig. 4).

Average spleen weights in Expt 3 were as follows (mg/mouse): 70, 111, 108, 8 and 9 (anti-logs of natural log-transformed means, pooled SEM 0.097) for groups B, C:saline, C:SRBC, LP:saline and LP:SRBC respectively. The LP groups of Expt 3, therefore, exhibited splenic atrophy which was comparable with that observed in the malnourished animals of the preceding experiment (Table 3). Consequently, the LP groups exhibited small numbers of Ig-containing cells per spleen relative to the corresponding saline- or SRBC-injected animals of group C (Fig. 4), despite maintaining high numbers of splenic Igcontaining cells per $\mathrm{mm}^{2}$ histological section area (results not shown).

Studies of germ-free mice reveal that gut microflora provide the main antigenic stimulus in support of the IgA-containing cell population of the intestinal lamina propria (Crabbe et al. 1968). Not more than $10 \%$ of the total number of intestinal IgA-containing cells could be attributed to other sources of antigen, e.g. dietary components. In another investigation the egg-white protein, ovalbumin, failed to elicit an intestinal IgA response when administered to adult rats by the oral route (Wold et al. 1989). It is unlikely, therefore, that the depressive influence of the LP protocol on the intestinal IgA-producing system resulted from under-exposure to food protein antigens in the present investigation. Nevertheless, if dietary egg white were to exert an unusually potent intestinal antigenic stimulus, then interpretation of the present results as being related to PEM, per se, might be confounded. Consequently, the IgA content of the intestinal lumen was compared in male C57BL/6J mice fed ad lib. from 19 to $33 \mathrm{~d}$ of age on either the egg-white-based purified diet used throughout this investigation or a similar purified diet based on casein 


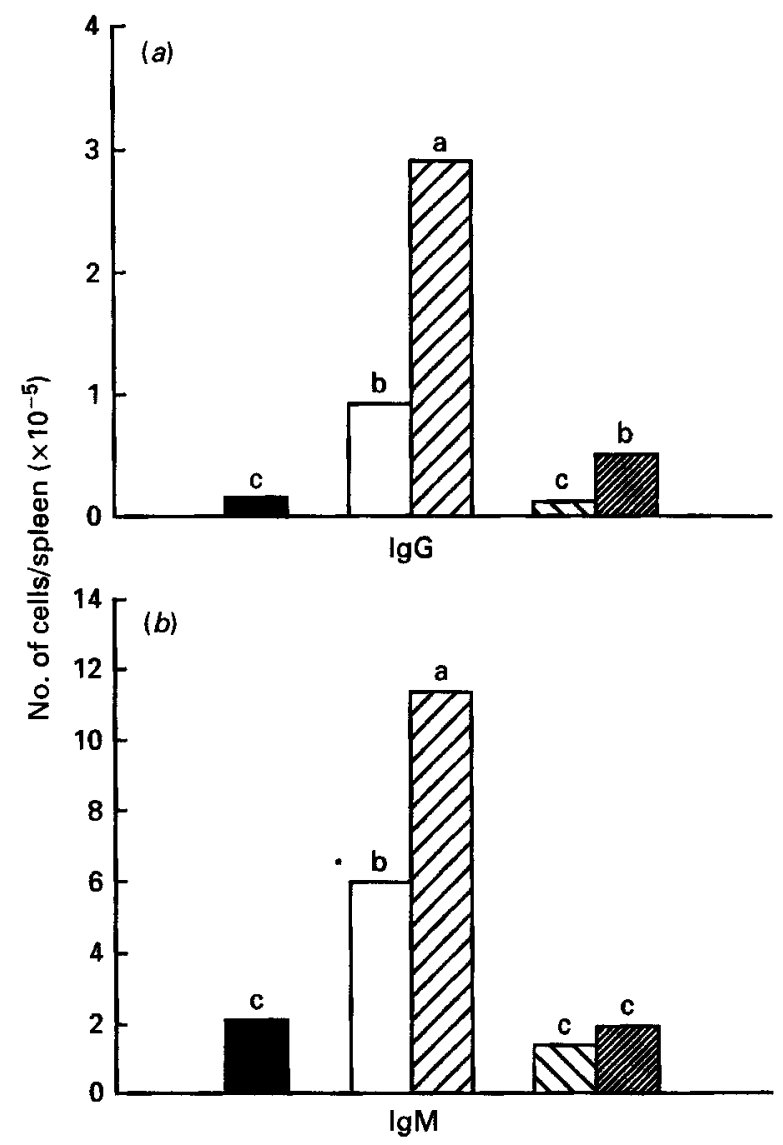

Fig. 4. Expt 3. Numbers of spleen cells containing immunoglobulin (Ig) of (a) IgG or (b) IgM class. Values are anti-logs of natural log-transformed mean values. Within each Ig class, values not sharing a common superscript letter were significantly different $(P<0.05)$ according to Duncan's new multiple-range test. Pooled SEM 0.3228 and 0.1658 for nos. (natural log-transformed data) of $\mathrm{IgG}$ - and IgM-containing cells respectively. ( $\mathrm{C}$ ), Group B, 19 d-old zero-time control; $(\square)$, saline $(9 \mathrm{~g} \mathrm{NaCl} / \mathrm{l})$ and $(\mathrm{Q})$, sheep erythrocytes (SRBC), group C, 33-d-old,

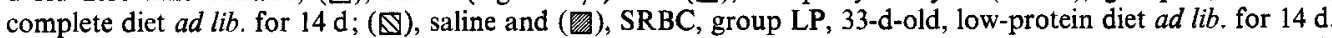
SRBC $\left(4 \times 10^{8}\right)$ were administered intraperitoneally at $12,18,24$ and $30 \mathrm{~d}$ of age and saline was sham-injected group B were given SRBC injections at 12 and $18 \mathrm{~d}$ of age. $n 7,4,8,4$ and 8 for groups B, C:saline, C:SRBC, LP:saline and LP:SRBC respectively. For details of experimental procedures, see pp. $446-449$.

(high N; catalogue no. 12845; US Biochemical). The latter was chosen because it is the protein source for the American Institute of Nutrition purified diet for laboratory rodents (Reeves et al. 1993). The egg-white- and casein-based diets contained 190 and $198 \mathrm{~g}$ crude protein/kg respectively on a wet weight (as-fed) basis. Gut lumen IgA content was as follows (mean; $\mu \mathrm{g} \mathrm{IgA} \mathrm{per} \mathrm{animal):} 110$ (SD 53.1) and 132 (SD 62.6) in the groups fed on the casein-based diet $(n 5)$ and the egg-white-based diet $(n 6)$ respectively. According to twotailed Student's $t$ test, therefore, egg white and at least one unrelated protein source commonly used in diet formulation did not differ in their net influence on the developing intestinal IgA-producing system $(P>0-5)$. It is unlikely that interpretation of the present results as primarily $P E M-$ related is compromised either by the choice of dietary protein source or by the use of a model of PEM in which exposure to dietary protein antigens is low. 


\section{DISCUSSION}

In the present investigation the gut-associated (i.e. mucosal) and splenic (i.e. systemic) antibody-producing systems responded similarly, in terms of effector cell numbers, in weanling mice subjected to wasting PEM according to an experimental protocol known (Woods \& Woodward, 1991; Woodward \& Miller, 1991) to depress systemic antibody responses. This conclusion is based on a direct comparison of cellular numbers within the two effector compartments in the same experimental subjects. Ideally, the two antibodyproducing systems would be compared on the basis of responsiveness to the same defined antigen, but this approach was impractical because the two systems exhibit differing response kinetics. In the present investigation the comparison in terms of cellular numbers was achieved by means of a quantitative analysis not subject to the unconscious errors which characterize analysis by observational histology. Inclusion of a zero-time control group was a key feature of design in the present investigation. Without this group, the phenomenon of reduced expansion in numbers of Ig-containing cells would not have been apparent and could easily have been misinterpreted as atrophy. Finally, the results appear independent of the differing extent to which the gut-associated and systemic antibodyproducing systems are normally exposed to antigenic challenge. The following paragraphs expand on these points whereby the present results represent a meaningful extension and refinement of previously available information pertaining to systemic and mucosal antibody-producing cellular systems in PEM.

For the purpose of the present investigation it was necessary to use an experimental model which duplicates critical features of human PEM in relation to $\operatorname{IgA}$, the $\operatorname{Ig}$ isotype characteristic of mucosal immunity. To that end we demonstrated herein that the model of weanling malnutrition used in the present investigation mimics human PEM in terms of IgA concentrations in blood plasma and the lumen contents of the intestine. In addition, previous investigations have shown that this experimental system also duplicates other important characteristics of human PEM. In particular, profound depression is apparent in systemic, thymus-dependent and -independent acquired immunity (Filteau et al. 1987; Woods \& Woodward, 1991; Woodward \& Miller, 1991) as well as in innate defence (Ingram et al. 1995). Moreover, the LP diet used in the present investigation, when fed to weanling mice for more than 4 weeks, produces fatty liver (S. M. Filteau \& B. Woodward, unpublished results) as well as low serum protein concentration and oedema (Filteau \& Woodward, 1987).

It is particularly remarkable that the LP animals, despite extreme wasting disease, could support expansion of both systemic and gut-associated humoral effector compartments, albeit an attenuated expansion relative to that observed in group $\mathrm{C}$ animals. Moreover, this was accomplished despite profound involution, in the LP system, both of the B-cell pool (Woodward \& Miller, 1991) from which all immunoglobulin-containing cells arise and of the peripheral thymic lymphocyte system (Woodward \& Miller, 1991) on which development of IgA- and IgG-containing cells depends (Abbas et al. 1991). Within the present data set, numbers of IgA- and IgG-containing cells are the most important indicators of humoral immunocompetence in mucosal and systemic sites respectively. Cells producing these classes of antibody represent the endpoint of a process of differentiation which includes Ig class switching from IgM (Abbas et al. 1991). The ratio of the number of cells containing IgG or IgA:number of IgM-containing cells indicates the extent to which Ig class switching is achieved within secondary lymphoid organs (Alverdy et al. 1992). In the present investigation the ratio of $\operatorname{IgA-:}$ IgM-containing cells was $7 \cdot 0$ and $14 \cdot 5$ in the intestinal lamina propria of mice from groups C and LP respectively (derived from Fig. 2). Similarly, the ratio of splenic IgG-:IgM-containing cells was 0.23 and 0.22 
respectively in animals of groups $\mathrm{C}$ and LP which were not subjected to systemic challenge with antigen (derived from Fig. 3). When subjected to systemic challenge with SRBC antigens, both LP mice and group $\mathrm{C}$ animals supported an increase in numbers of splenic IgG-containing cells (indicative of a mature antibody response) relative to saline-injected controls, and the ratio of splenic IgG-:IgM-containing cells was 0.26 and 0.27 in groups $C$ and LP respectively (derived from Fig. 4). The heterologous erythrocyte elicits a wellcharacterized thymus-dependent antibody response (Foy et al. 1993), and exhibits Forssman antigens as are found, also, on microfloral organisms (Talmage et al. 1956). This is, therefore, a physiologically relevant immunogen which exerts an antigenic challenge resembling that to which the mucosal antibody-producing system is exposed. Assuming, therefore, that PEM does not increase the lifespan of Ig-containing cells, a period of a few days in the mouse (Mattioli \& Tomasi, 1973), the present results permit the conclusion that the process of Ig class switching is intact in both systemic and mucosal sites in the LP model of weanling PEM.

The present results are consistent with previous evidence (Lopez \& Roux, 1989) suggesting that wasting PEM in weanling rodents inhibits differentiation of pre-B cells. By analogy with X-linked agammaglobulinaemia (Abbas et al. 1991), such a (partial) developmental arrest would produce the profound reduction in B-cell numbers known to occur in mice subjected to the experimental system used in the present investigation (Woodward \& Miller, 1991), while preserving the relative proportions of cells producing different classes of $\mathrm{Ig}$ (present investigation). It is probable that PEM also influences later stages in the genesis of Ig-containing cells. For example, interleukins 2 and 6 promote final differentiation and proliferation of both IgG- and IgA-containing cells (Abbas et al. 1991; Ramsay et al. 1994), but the capacity to produce these cytokines appears low in PEM (McMurray et al. 1989; Doherty et al. 1994). Up to the point of plasma cell differentiation, however, no fundamental difference is discernible, from the present investigation, between the responses of the mucosal and systemic antibody-producing systems to the form of experimental PEM induced by the LP protocol.

A high proportion of Ig-containing cells in both systemic and mucosal sites derive from the Ly-1 B-cell lineage and produce low-affinity, polyreactive antibody of all major classes (Kroese et al. 1992). The remaining Ig-containing cells are of the bone-marrow-derived 'conventional' lineage, and produce high-affinity monoreactive antibody which is generally regarded to reflect a fully mature humoral immune response. It remains possible that PEM disrupts the balance in numbers between Ig-containing cells of Ly-1 and of conventional lineages. This would be consistent with results suggesting that the systemic humoral response in PEM generates low-affinity antibody (Chandra, 1991), and such an imbalance could develop within systemic and/or mucosal sites.

The present investigation illustrates the importance of including a zero-time control group in studies of the immune system in weanling PEM. This strategy is seldom employed in work with experimental animals and is often either unethical or difficult to put in place in studies of human subjects. Without a zero-time control group, the phenomenon of reduced expansion in numbers of Ig-containing cells would not have been apparent in the LP mice of the present investigation and could easily have been misinterpreted as atrophy. These results suggest a need to re-evaluate the widely-held belief (Green \& Heyworth, 1980; Wade et al. 1982; Brunser et al. 1990; Chandra \& Wadhwa, 1993) that PEM induces involution in the humoral effector compartment of the intestinal mucosa. Further to this point, observational studies have suggested low numbers of gut-associated Ig-containing cells in experimental animals (Green \& Heyworth, 1980; Wade et al. 1982; Brunser et al. 1990; Chandra \& Wadhwa, 1993), whereas splenic Ig-containing cellular numbers are usually reported to be preserved (Gross \& Newberne, 1980). The present investigation 
demonstrates that this putative difference between the influence of PEM on gut mucosal and splenic sites (as to Ig-containing cellular numbers per unit section area) is an artifact of the different degrees of involution of these organs.

Low concentrations of IgA in various mucosal secretions including tears, saliva and nasal washings are reported, together with high serum IgA levels, in wasted children (Sirisinha et al. 1975; McMurray et al. 1977). In addition, low concentrations of free secretory component have been reported in tears of wasted children (Watson et al. 1985) and in tears, saliva and intestinal washings of malnourished rats (Sullivan et al. 1993). Because of these results it has been suggested that PEM exerts a depressive influence on the epithelial transport of IgA to its mucosal site of action (Chandra \& Wadhwa, 1993). The present results provide independent experimental support for this hypothesis inasmuch as biliary $\operatorname{IgA}$ concentration and the quantity of $\operatorname{IgA}$ within the contents of the intestinal lumen both were low in the LP mice despite their high serum IgA concentration. Wasting PEM, when produced in weanling rodents by means of a low-protein diet, is accompanied by high intestinal permeability to lumen antigens (Rothman et al. 1982). Any upward pressure exerted on plasma immunoglobulin concentrations by increased systemic exposure to intestinal macromolecules, however, will mainly affect the IgG and IgM classes of immunoglobulin, whereas the present results revealed no effect of the LP protocol on serum IgM concentration. Other results (Ha \& Woodward, 1994) suggest that reduction in the quantity of intestinal and hepatic polymeric Ig receptors (from which secretory component is derived) can account substantially for the low gut-lumen IgA content induced by the LP protocol used in the present investigation. The apparent difference in sensitivity to PEM between systemic and mucosal humoral immunity, therefore, may be attributable largely to the unique requirement for transport of mucosal antibody across epithelial barriers.

In summary, a murine model of weanling PEM has been investigated which mimics the human condition in terms of important aspects of IgA concentration (present study) and systemic acquired immunity, both humoral and cell-mediated (Woods \& Woodward, 1991; Woodward \& Miller, 1991). Use of the LP model illustrates expansion of both gut mucosal and splenic (systemic) humoral effector compartments in the face of profound wasting disease, an expansion which would not be predicted from measurements of biliary or gut-lumen $\operatorname{IgA}$ content (this investigation), or from previous measurements of systemic antibody responsiveness in this experimental model (Woods \& Woodward, 1991; Woodward \& Miller, 1991). The results, therefore, highlight the resistance of antibodyproducing cellular systems to the influence of wasting PEM but, at the same time, provide an experimental basis for focusing attention on epithelial transport of $\operatorname{IgA}$ as an immunological process sensitive to this disease.

This work was supported by a grant to B.W. from the Natural Sciences and Engineering Research Council of Canada. The authors gratefully acknowledge the technical assistance of Mrs Vera Peacock and Mrs Lyn Hillyer in the analysis of carcass composition.

\section{REFERENCES}

Abbas, A. K., Lichtman, A. H. \& Pober, J. S. (1991). Cellular and Molecular Immunology. Philadelphia: W. B. Saunders.

Alverdy, J. A., Aoys, E., Weiss-Carrington, P. \& Burke, D. A. (1992). The effect of glutamine-enriched TPN on gut immune cellularity. Journal of Surgical Research 52, 34-38.

Barry, W. S. \& Pierce, N. F. (1979). Protein deprivation causes reversible impairment of mucosal immune response to cholera toxoid/toxin in rat gut. Nature 281, 64.65.

Beatty, D. W., Napier, B., Sinclair-Smith, C. C., McCabe, K. \& Hughes, E. J. (1983). Secretory IgA synthesis in kwashiorkor. Journal of Clinical and Laboratory Immunology 12, 31-36.

Bell, R. G., Turner, K. J., Gracey, M., Suharjono \& Sunoto (1976). Serum and small intestinal immunoglobulin levels in undernourished children. American Journal of Clinical Nutrition 29, 392-397.

Brunser, O., Araya, M. \& Espinoza, J. (1990). Gastrointestinal tract changes in the malnourished child. In The 
Malnourished Child, pp. 261-276 [R. M. Suskind and L. Lewinter-Suskind, editors]. New York: Vevey/Raven Press.

Chandra, R. K. (1975). Reduced secretory antibody response to live attenuated measles and poliovirus vaccines in malnourished children. British Medical Journal 2, 583-585.

Chandra, R. K. (1991). Nutrition and immunity: lessons from the past and new insights into the future. American Journal of Clinical Nutrition 53, 1087-1101.

Chandra, R. K. \& Wadhwa, M. (1993). Nutritional deficiencies and intestinal mucosal immunity. In Immunophysiology of the Gut, pp. 389-399 [W. A. Walker, P. R. Harmatz and B. K. Wershil, editors]. San Diego: Academic Press.

Crabbe, P. A., Bazin, H., Eyssen, H. \& Heremans, J. F. (1968). The normal microbial flora as a major stimulus for proliferation of plasma cells synthesizing IgA in the gut. International Archives of Allergy 34, 362-375.

Delacroix, D. L., Malburny, G. N. \& Vaerman, J.-P. (1985). Hepatobiliary transport of plasma IgA in the mouse: contribution to clearance of intravascular IgA. European Journal of Immunology 15, 893-899.

Doherty, J. F., Golden, M. H. N., Remick, D. G. \& Griffin, G. E. (1994). Production of interleukin-6 and tumour necrosis factor- $\alpha$ in vitro is reduced in whole blood of severely malnourished children. Clinical Science 86, 347-351.

Filteau, S. M., Berdusco, E., Perry, K. J. \& Woodward, B. (1987). The effect of triiodothyronine on evanescent delayed hypersensitivity to sheep red blood cells and on the primary antibody response to trinitrophenylated Brucella abortus in severely undernourished weanling mice. International Journal of Immunopharmacology 9 , 811-816.

Filteau, S. M. \& Woodward, B. (1984). Relationship between serum zinc level and immunocompetence in proteindeficient and well-nourished weanling mice. Nutrition Research 4, 853-866.

Filteau, S. M. \& Woodward, B. (1987). Influence of severe protein deficiency and of severe food intake restriction on serum levels of thyroid hormones in the weanling mouse. Nutrition Research 7, 101-107.

Foy, T. M., Shepherd, D. M., Durie, F. H., Aruffo, A., Ledbetter, J. A. \& Noelle, R. J. (1993). In vivo CD40-gp39 interactions are essential for thymus-dependent humoral immunity. II. Prolonged suppression of the humoral immune response by an antibody to the ligand for CD40, gp39. Journal of Experimental Medicine 178, $1567-1575$.

Green, F. \& Heyworth, B. (1980). Immunoglobulin-containing cells in jejunal mucosa of children with protein-energy malnutrition and gastroenteritis. Archives of Disease in Childhood 55, 380-383.

Gross, R. L. \& Newberne, P. M. (1980). Role of nutrition in immunologic function. Physiological Reviews 60, $188-302$.

Ha, C.-L. \& Woodward, B. D. (1994). Reduced IgA in intestinal lumen and low hepatic secretory component (SC) in weanling malnutrition. Canadian Federation of Biological Societies 74, Abstr.

Harlow, E. \& Lane, D. (1988). Antibodies: a Laboratory Manual. New York: Cold Spring Harbor Laboratory.

Horwitz, W. (1980). Official Methods of Analysis of the Assaciation of Official Analytical Chemists, 13th ed. Washington, DC: Association of Official Analytical Chemists.

Ingram, K. G., Croy, B. A. \& Woodward, B. D. (1995). Splenic natural killer cell activity in wasted, protein-energy malnourished weanling mice. Nutrition Research 15, 231-243.

Keet, M. P. \& Thom, H. (1969). Serum immunoglobulins in kwashiorkor. Archives of Disease in Childhood 44, 600-603.

Kroese, F. G. M., Ammerlaan, W. A. M. \& Deenen, G. J. (1992). Location and function of B-cell lineages. Annals of the New York Academy of Sciences 651, 44-58.

Lim, T. S., Messiha, N. \& Watson, R. R. (1981). Immune components of the intestinal mucosae of ageing and protein deficient mice. Immunology 43, 401-407.

Lopez, M. C. \& Roux, M. E. (1989). Impaired differentiation of IgA-B cell precursors in the Peyer's patches of protein depleted rats. Developmental and Comparative Immunology 13, 253-262.

McGee, D. W. \& McMurray, D. N. (1988a). The effect of protein malnutrition on the IgA immune response in mice. Immunology 63, 25-29.

McGee, D. W. \& McMurray, D. N. (1988b). Protein malnutrition reduces the IgA immune response to oral antigen by altering B-cell and suppressor T-cell functions. Immunology 64, 697-702.

McMurray, D. N., Mintzer, C. L., Bartow, R. A. \& Parr, R. L. (1989). Dietary protein deficiency and Mycobacterium bovis BCG affect interleukin-2 activity in experimental pulmonary tuberculosis. Infection and Immunity 57, 2606-2611.

McMurray, D. N., Rey, H., Casazza, L. J. \& Watson, R. R. (1977). Effect of moderate malnutrition on concentrations of immunoglobulins and enzymes in tears and saliva of young Colombian children. American Journal of Clinical Nutrition 30, 1944-1948.

Mattioli, C. A. \& Tomasi, T. B. Jr (1973). The life span of IgA plasma cells from the mouse intestine. Journal of Experimental Medicine 138, 452-460.

Mayhew, T. M. \& Williams, M. A. (1974). A quantitative morphological analysis of macrophage stimulation. II. Changes in granule number, size and size distributions. Cell and Tissue Research 150, 529-543.

Ojeda, J. L., Ros, M. A. \& Icardo, J. M. (1989). A technique for fluorescence microscopy in semithin sections. Stain Technology 64, 243-248.

Ramsay, A. J., Husband, A. J., Ramshaw, I. A., Bao, S., Matthaei, K. I., Koehler, G. \& Kopf, M. (1994). The role of interleukin-6 in mucosal IgA antibody responses in vivo. Science 264, 561-563. 
Reddy, V., Raghuramulu, N. \& Bhaskaram, C. (1976). Secretory IgA in protein-calorie malnutrition. Archives of Disease in Childhood 51, 871-874.

Reeves, P. G., Nielsen, F. H. \& Gahey, G. C. Jr (1993). AIN-93 purified diets for laboratory rodents : final report of the American Institute of Nutrition Ad Hoc Writing Committee on the reformation of the AIN-76A rodent diet. Journal of Nutrition 132, 1939-1951.

Rothman, D., Latham, M. C. \& Walker, W. A. (1982). Transport of macromolecules in malnourished animals. I. Evidence for increased uptake of intestinal antigens. Nutrition Research 2, 467-473.

Sirisinha, S., Suskind, R., Edelman, L. T. C. R., Asvapaka, C. \& Olson, R. E. (1975). Secretory and serum IgA in children with protein-calorie malnutrition. Pediatrics 55, 166-170.

Slobodianik, N. H., Cosarinsky, R. C., Langini, S. H., Roux, M. R., Rio, M. E. \& Sanahuja, J. C. (1984). Effect of severe protein deficiency on surface and intracellular markers of growing rats' lymphoid organs. Nutrition Reports International 29, 957-964.

Statistical Analysis Systems (1985). SAS User's Guide, Statistics. Cary, NC: SAS Institute Inc.

Steihm, E. R. (1980). Humoral immunity in malnutrition. Federation Proceedings 39, 3093-3097.

Sullivan, D. A., Vaerman, J.-P. \& Soo, C. (1993). Influence of severe protein malnutrition on rat lacrimal, salivary and gastrointestinal immune expression during development, adulthood and ageing. Immunology 78, 308-317.

Talmage, D. W., Freter, G. G. \& Taliaferro, W. H. (1956). The effect of repeated injection of sheep red cells on the hemolytic and combining capacities of rabbit antiserums. Journal of Infectious Diseases 98, 293-299.

van Noorden, S. (1986) Tissue preparation and immunostaining techniques for light microscopy. In Immunocytochemistry: Modern Methods and Application, pp. 26-53 [J. M. Polak and S. van Noorden, editors]. Bristol: Wright.

Wade, S., Lemonnier, D., Alexiu, A. \& Bocquet, L. (1982). Effect of early postnatal under- and overnutrition on the development of IgA plasma cells in mouse gut. Journal of Nutrition 112, 1047-1051.

Watson, R. R. (1984). Nutritional stresses: alterations in mucosal immunity and secretory $\operatorname{lgA}$. In Nutrition, Disease Resistance, and Immune Function, pp. 189-204 [R. R. Watson, editor]. New York: Marcel Dekker.

Watson, R. R., McMurray, D. N., Martin, P. \& Reyes, M. A. (1985). Effect of age, malnutrition and renutrition on free secretory component and IgA in secretions. American Journal of Clinical Nutrition 42, $281-288$.

Watson, R. R., Reyes, M. A. \& McMurray, D. N. (1978). Infiuence of malnutrition on the concentration of IgA, lysozyme, amylase, and aminopeptidase in children's tears. Proceedings of the Society for Experimental Biology and Medicine 157, 215-219.

Weibel, E. R. \& Bolender, R.P. (1973). Stereological techniques for electron microscopic morphometry. In Principles and Techniques of Electron Microscopy. Biological Applications, vol. 3, pp. 237-296 [M. A. Hayat, editor]. New York: Van Nostrand Reinhold.

Wold, A. E., Dahlgren, U. I. H., Hanson, L. A., Mattsby-Baltazer, I. \& Midvetdt, T. (1989). Difference between bacterial and food antigens in mucosal immunogenicity. Infection and Immunity 57, 2666-2673.

Woods, J. W. \& Woodward, B. D. (1991). Enhancement of primary systemic acquired immunity by exogenous triiodothyronine in wasted, protein-energy malnourished weanling mice. Journal of Nutrition 121, $1425-1432$.

Woodward, B. D. \& Miller, R. G. (1991). Depression of thymus-dependent immunity in wasting protein-energy malnutrition does not depend on an altered ratio of helper $\left(\mathrm{CD} 4^{+}\right)$to suppressor $\left(\mathrm{CD} 8^{+}\right) \mathrm{T}$ cells or on a disproportionately large atrophy of the $\mathbf{T}$-cell relative to the B-cell pool. American Journal of Clinical Nutrition $53,1329-1335$. 